\title{
Brief to the Senate Standing Committee on Legal and Constitutional Affairs Concerning Bill C-84
}

\author{
The Inter-Church Committee for Refugees \\ October 1, 1987
}

\section{Summary of Concerns}

We believe the measures of Bill C-84 fail to address the reality of international, national and humanitarian concerns as follows:

a) they do not satisfy UNHCR Convention and Protocol Obligations;

b) they violate the Canadian Charter of Rights and Freedoms;

c) they do not meet international, national and individual purposes since genuine refugees are not protected, and smug. glers and unscrupulous consultants are not targeted;

d) the introduction of arbitrary and discretionary powers with little accountability of those responsible without constitutional safeguards for the individual are measures normally associated with a totalitarian state.

Upholding the 1951 Convention and 1967 Protocol.

The government has repeatedly and publicly stated its intention to honour the 1951 Convention and 1967 Protocol to which Canada is a contracting state. This is one of the objectives of the current Immigration Act 1976. The key elements of the Convention and Protocol are to allow asylum seekers to present their claim on arrival as well as to prevent their forced return home, whether directly or by a third country. As the High Commissioner for Refugees pointed out in his 'Aide Memoire' of June 1987:

We cannot entertain domestic law which in any way undermines the intent of these treaties. In discussion with the Legislative Committee on Bill C-84, the representatives of the UNHCR made clear the need to hear the individual claim before applying exclusion clauses on grounds such as security (Minutes 3;9):

Bill C-84, Clause 5, 'Denial of Access' to refugee determination process, and Clause 8 , 'Interdiction of Ships' do not conform with this understanding of Canada's obligations under the Convention and Protocol.

\section{Violation of the Canadian Charter of Rights and Freedoms}

The ICCR wishes to address the relevance of the Canadian Charter to Bill C-84 because it is critical to Canadian standards of justice. First, with respect to 'Expression of Conscience' (S.2.) and penalties, Bill C-84 (Clause 9) could penalize those who in good conscience seek to protect a refugee by advising him of the possibility of making a claim in Canada.

Second, with respect to the procedures conforming with fundamental principles of justice (S.7), the 'Security Review' procedure of Bill C-84 (Clause 2) does not allow counsel nor does it allow the person early opportunity to respond to evidence used against him. Clause 4 permits extended loss of liberty without due process of review. Clause 5, 'Denial of Access to Refugee Process' denies certain rights of a refugee without a procedure conforming with the fundamental principles of justice. Clause 8, 'Interdiction of Ships', like Clause 5, denies rights of refugees in Canada without due process. And Clause 12 , 'Detention', gives no just process for extended removal of liberty.

Third, security against unreasonable search and seizure (S.8) would be threatened by Bill Clause 11 of Bill C-84, especially if compounded with Clause 9 , since it may allow unreasonable search and seizure.

Fourth, protection from arbitrary arrest and detention (Section 9, 10) is compromised by Bill C-84, in Clause 4 because the security review procedure withholds reasons for detention and limits rights of review as does Clause 12 on 'Detention.'

Fifth, protection from cruel treatment in the Charter (S.12) is threatened by Bill C. 84, Clause 8, 'Interdiction of Ships', could result either in further travel of passengers under unacceptable conditions on ship or durmping of passengers at sea.

Sixth, protection from discrimination (S.15) is not satisfied by Bill C-84 under Clause 4 since the 'Security Review
Procedure' separates residents from nonresidents in the standards of justice received. And under Clause 8, 'Interdiction of Ships' singles out one method of transportation for special penalties.

Toward Effective, Efficient, Fair and Enforceable Measures

The legislation must be enforceable. To elicit cooperation necessary to facilitate enforcement, measures must be seen to be fair and appropriate to the purpose at hand. Several of the measures of Bill C-84 can be questioned on these grounds.

Clause 1(a) uses language which conflicts with another purpose, to uphold the Convention and Protocol. Clauses 2 and 4 introduce a new security review procedure yet tightening the time frame for the existing procedure would be simpler, as efficient, and more just. Clauses 4 and 12 introduce excessive and unnecessary measures for security review and detention. Existing provisions for detention and review of detention are adequate. Clause 8, 'Interdiction of Ships', is likely to be ineffective, whereas escorting the ship to port and charging the captain would be more effective. Clause 9 is ineffective and difficult to enforce in focussing penalties on smugglers and unscrupulous consultants. Clauses 10 and 14 place unrealistic obligations on transportation companies. Clause 11 is largely unnecessary because existing authority was adequate with respect to the Canadian experience to date, namely the Sikh arrivals in Summer 1987.

Accountability for Exercise of Discretion

The ICCR membership is gravely concerned about the totalitarian measures reflected in Bill C-84's introduction of arbitrary and discretionary powers with little accountability and without constitutional safeguards for the individual. The Bill sets a priority on using discretion to protect a certain view of national sovereignty at minimal cost. Clauses 2, 3 and 4, for example, provide discretion to designate a security case, and discretion to have a security case detained. Clause 5 provides 


\section{Senate Brief, ICCR Cont'd from page 6}

discretion to deny refugee determination on security grounds. Clause 8 provides discretion to turn away a ship. Clause 9 provides discretion to apply penalties within a broadly defined group. Clause 11 provides discretion to search and seize with slender safeguards. Clause 12 provides discretion to detain on basis of identity. Clause 14 provides discretion to require airlines to hold documents.

Churches have reflected on the conflict between the right of a state to protect its sovereignty by maintaining its borders and the rights of an individual to flee and to seek asylum. If the individual is fleeing persecution, the priority must be with the individual. Any process must have safeguards to protect such persons. In the absence of clearly defined limits on the application of discretionary powers, this legislation must make every effort to ensure that maximum safeguards for the individuals involved are employed.

\section{Specific Amendments}

1) Purpose Clause I(a), (s.2.1)

The wording of this clause implies a more limited protection than the Convention and Protocol. The language should be consistent with the purpose of protecting refugees under the Convention and Protocol. Replace Clause 1(1):

to ensure that refugees are protected from removal to a country where their lives or freedom may threatened.

2) Security Cases Clause 2(1) (s.39(2) \& (3)) Clause $3(s .40(1))$ and Clause 4 (s.4l(1))

These clauses take non-permanent residents out of the present security review and do not give a proper review on the basis of the merits of the case. Speed seems to be the intent. The new process may conflict with Charter section 15 on grounds of discrimination between permanent and non-permanent residents. The immediate issue of a security certificate is discretionary rather than the result of due process. The new process excludes a person from hearing the Minister's case. Normal rules of evidence do not apply, conflicting with the Charter's section 7 intent for a just process. Persons can be detained without review for up to 120 days. The Federal Court judge can only determine whether the Minister acted reasonably on the basis of his evidence. This provides no appeal of the merits of the case. The new process does not use a specialized expert body to review decisions and is therefore less effective.

The presumed need for increased efficiency can be more simply achieved by setting a time frame for the present process. The unnecessary provisions which deny safeguards for the individual must be deleted. The specialized security agency has been recognized as the most suitable body to use. Whatever happens, there must be a review on the merits and, as of now, there must be detention only if the person poses a danger to the public.

The ICCR recommends that the Legislature support the Canadian Bar Association proposals which specifically address the above points.

3) No Access to Refugee Determination Procedure Clause 5 (s.48.1)

The clause prevents some security risk cases from having their refugee claim determined and from having the opportunity to find a country other than the country of origin to which to return, as required by the Convention. This also denies refugee rights without a just process as required by Charter section 7. To send a person back to persecution could violate Charter section 12 by exposing the person to cruel or unusual treatment. A more effective alternative is to expedite refugee determination for such persons.

The ICCR recommends that the legislature replace Clause 5 with:

48(1) A person found to be a person described in paragraph $41(1)$ by the Review Committee, who has indicated an intention to claim refugee status, shall forthwith have his claim expedited.

4) Interdiction of Ships Clause 8 (s.91.1)

This clause allows the Minister to order a ship not to enter Canada's waters or to leave them if already there. The grounds for making the decision to do this are illspecified. Refugees cannot be determined as required by the Convention and
Machine Readable Data Base; International Computer Network Address

The Refugee Documentation Project's data base is being made available as a machine-readable resource. The system employs the UNESCO produced software, CDS/ISIS, adapted by our systems manager, Mr. Fisseha Abebe. The UNHCR Thesaurus, British Refugee Council Library Classification System, developed by Mr. Warwick Harris, and IBM compatible machines are employed. We welcome the exchange of files, and messages which will help us to develop a global directory. International network mail via BITNET should be addressed to us at: Refuge@YORKVM!

NEW PUBLICATIONS DOUBLE STANDARD: THE SECRET HISTORY OF CANADIAN IMMIGRATION. Reg. Whitaker. October 31, 1987, published by Lester \& Orpen Dennys Limited, 78 Sullivan Street, Toronto, ON, M5T ICl. Price \$24.95, hardcover, pp.360.

UNACCOMPANIED CHILDREN: Care and Protection in Wars, Natural Disasters, and Refugee Movements. November 1987, published by Everett M. Ressler, Neil Boothby and Daniel J. Steinbock, Oxford University Press, 70 Wynford Drive, Don Mills, $\mathrm{ON}, \mathrm{M} 3 \mathrm{C}$ IJN. Price $\$ 28.50$ softcover, pp. 425.

THE GUARDED GATE: The Reality of American Refugee Policy. Norman L. Zucker and Naomi Flink Zucker, November 30,1987 , published by Harcourt, Brace and Jovanovich, 111 Fifth Ave. New York NY 10003 USA. Price US \$22.95, hardcover. pp. 368.

Refugee Abstracts, a quarterly publication of the UNHCR's Centre for Documentation on Refugees (CDR) and special annotated bibliographic publications are available for sale. For a price list, index and other information write to: CDR - UNHCR, 5-7 avenue de la Paix, CH-1202 Geneva, Switzerland or Telex 27492 or 28741 UNHCR CH. 


\section{Effective Advocacy} Cont'd from page 1

Asian workers were deported or their departure coerced when the work was finished. And for decades, certain religious or racial groups remained the object of overt or covert discrimination: Jews, Blacks, Orientals and other Asians. Thus, the ideology held by those in authority, particularly as it became woven into the social structure as a legal instrument of state, affected the shape of Canada's laws and the socioeconomic and political status of its immigrant peoples for generations.

Canada's developmental growth and its immigration policies tend to have been accompanied by protectionism both during times of social and economic expansion or, conversely, during eras of restrictionism. Two examples are cited. First, they were evident in the early 1920s and affected Mennonite refugees fleeing revolution, war, political and religious persecution and famine in Russia. Canada admitted 21,000 Mennonites in an early wave. Later in that decade, both the Soviet and Canadian governments changed their policies: the Soviets would not let the Mennonites leave, and Canada would not let them enter. Still, thousands of desperate Mennonites travelled to Moscow seeking permission to leave. It was more than a year before the Soviet government did agree to let the rest go. But by that time the Canadian political climate had become very negative and, despite strong appeals by Canadian Mennonite leaders and their supporters, Canada firmly closed its doors. The Soviet government loaded the remaining estimated 10,000 Mennonite refugees into boxcars in the middle of winter and sent them away. "Hundreds froze to death. Many more were never heard from again."

A second example occurred during the onset and duration of World War II. Canada was not suffering from severe economic recession, nor was it overpopulated. Despite these facts, it remained deaf to pleas and provided safe haven for too few of the desperate peoples fleeing Third Reich persecution. Jews were notably excluded despite the fact that they were targeted for extermination in Europe. The then Prime Minster Mackenzie King stated that he "supported popular growth and economic development," but not at the expense of "distorting the character of the country." And his Immigration Minister, F. P. Blair, when asked how many Jews would be al-

lowed in, stated that 'none is too many.' It was during this era that moral outrage began to be expressed in the private sector and that effective advocacy had its birth.

Ministers, parliamentarians, political lobbyists and social activists began to voice their disapproval of government policy collectively. Member of Parliament, the Hon. A. A. Heap, also a member of Winnipeg's Jewish community, stated in a letter to Prime Minister Mackenzie King that Canada's immigration regulations were the most stringent in the world. And they were "inhuman" because they refused "the right of asylum to limited numbers of political and religious refugees." The principal of Queen's University added that " $A$ liberty loving country cannot afford to close the doors when persecuted people are looking for a hospitable home."

But Canada did close its doors and its shorelines too. Forty-eight years ago, the ship St. Louis was denied permission to land. Its human cargo of 930 Jewish refugees had been refused asylum from countries in South America, Central America, the Caribbean and the United States. Canada's refusal to grant fourth country safe haven was tantamount to signing the refugees' death warrants as the ship was forced to retum to Europe.

During this era, advocates were joined by business groups, non-governmental organizations (NGOs), and religious groups such as the Canadian Jewish Congress (CJC) and the Jewish Immigrant Aid Service (JIAS). Together they began to fight for the giving of refuge and not just political asylum to those fleeing from persecution. Canada became a signatory to the 1951 Geneva Convention and in 1969 adopted the UNHCR Protocol defining refugees. In the late 1970 s, the CJC and JIAS pressed the government to take greater state responsibility toward humanitarian refugees.' After considerable lobbying, the government did introduce a new 'designated class' category in the 1976 Immigration Act which provides for,

\begin{abstract}
any person who is a member of a class designated by the Governor in Council as a class, the admission of members of which would be in accordance with Canada's humanitarian tradition with respect to-the displaced and the persecuted.
\end{abstract}

Without making the term 'refugee' legal, any person so designated under this category can be assisted into Canada through government or private sponsorship or by immediate family members resident in Canada. In 1978, immigration regulations allowed sponsorship by legally incorporated organizations. National organizations could form umbrella agreements. Groups of five adult Canadians could sign sponsorship contracts. It was the practical response to need and a necessary adjunct to a special UNHCR pledging conference in Geneva, 1979. With such assistance from the private sector, Canada ultimately pledged to accept 40,000 Indochinese refugees as a "designated class.'

As well as organizations, individual Canadians played signal advocacy and assistance roles. They developed a 'Standing Conference of Citizens Concerned for Refugees' and they influenced colleagues and associates. They helped to form umbrella organizations, such as Operation Lifeline, which bridged between the government and the private sector. Thus, since 1979, Canada's humanitarian reputation has increased in tandem with its intake of the now more than 95,000 Indochinese refugees who have been sponsored and assisted through government and private sector cooperation.

Amongst the very first religious bodies to offer sponsorship and aid to the Indochinese refugees were the Mennonite, Lutheran and Christian Reform Churches in Canada. Each year they have increased the previous year's sponsorship rates of individuals and families, especially women refugees and those with physical or mental handicaps. The Christian Reformed Churches in Canada, for example, together with sponsorship, conduct programmes which provide regular education about global refugee conditions, needs and problems, alternative methods for providing relief and rehabilitation to refugees abroad; review and response to government policies and legislation effecting Canada and the world refugee. A second example is that Catholic dioceses throughout Canada have arranged 'umbrella' sponsorships by parish groups within a supportive context of diocesan-based social services. This model has proved extremely effective in assuring greater participation within a single faith group by providing a base for replenishment of sponsoring groups. The success of responsive church ministries, together with those of national organizations is portrayed in the following table.

Clearly, as in the past, there is a positive humanitarian response from the private 


\section{Effective Advocacy Cont'd from page 8}

sector. Through the formation of umbrella groups and coalitions, structural links increase as individuals, NGO and church groups continue to press the Canadian government with respect to the repressive and restrictive natures of Bills C-55 and C84. If passed, these Bills would amend the 1976 Immigration Act. The briefs to par-

allocated for refugee relief. AI receives no government funding, deriving more than $90 \%$ of its funds from private sector donations.

The Mennonite Central Committee in Canada (MCCC), one of the first church groups to make a private sponsorship commitment, is the international relief and development organization of the Mennonite and Brethren-in-Christ churches of Cana-

Private Group Sponsorships: Organizations Calendar Years 1982-1986

Canadian Polish Congress

Roman Catholic Churches

Counc. Christian Reform. Churs.

Mennonite Central Committee

United Church

Anglican Church

Ukranian Canadian Committee

Presbyterian Church

Polish Alliance of Canada

Canadian Lutheran World Church

Czechoslovakian National Assoc.

Baptist Church

National Baha' is Assembly

World University Svc. of Canada

Seventh Day Adventist Church

Christian \& Missionary Alliance

Other National Organizations

Local Groups

\begin{tabular}{rrrrr}
1982 & 1983 & 1984 & 1985 & 1986 \\
\hline 859 & 251 & 427 & 808 & 1.717 \\
852 & 631 & 673 & 934 & 1.475 \\
$193^{*}$ & 254 & 462 & 405 & 656 \\
226 & 223 & 297 & 400 & 548 \\
163 & 118 & 118 & 289 & 404 \\
20 & 14 & 30 & 171 & 383 \\
71 & 39 & 48 & 137 & 178 \\
22 & 34 & 79 & 96 & 176 \\
342 & 142 & 27 & 59 & 135 \\
62 & 64 & 55 & 56 & 73 \\
27 & 37 & 41 & 37 & 58 \\
61 & 55 & 47 & 38 & 57 \\
62 & 165 & 169 & 93 & 36 \\
18 & 30 & 43 & 21 & 36 \\
9 & 37 & 28 & 26 & 21 \\
18 & 16 & 19 & 12 & 16 \\
94 & 35 & 110 & 97 & 581 \\
713 & 517 & 460 & 1,251 & $1,284^{* *}$ \\
4,597 & 2.671 & 3,178 & 4,957 & 7,887
\end{tabular}

* Figures show refugee and designated class immigrants covered by group sponsorship applications submitted during calendar year.

** Includes 707 persons whose sponsorships were concluded early Jan/Feb, 1982, and for whom no breakdown by organization is available. Figures unavailable for other organizations.

Settlement Branch, CEIC, November 1987

liament of three such organizations have been reproduced and are contained in this edition of Refuge. An outline of their mandates, organization and work follows.

Amnesty International (AI) is an independent worldwide movement. It has consultative status with the United Nations (ECOSOC), UNESCO and the Council of Europe. AI's focus is on the release of 'prisoners of conscience.' The organization advocates fair and early trials, opposes the death penalty and torture or other inhuman treatment of all prisoners, without reservation. It has cooperative relations with many international and regional human rights organizations; for example, the Organization of African Unity. Established in 1971, Al Canada Section today comprises approximately 200 Groups. The national refugee case load averages 100-150 cases each year. A special unit on Refugee Coordination lobbies on individual cases both within and beyond the Canadian border. It draws from a continually replenished fund of $\$ 10,000$ da and represents approximately 150,000 people. Most work is done jointly with MCC U.S. through a binational organization which is active in 50 countries. A Chicago representative, for example, Coordinator of the "Overground Railroad", assists Central Americans in the U.S. to apply for refugee status at Canadian Consulates. It is from their current involvement with refugees that MCCC representatives addressed the gravity of Bill C-55 in their brief to Parliament. Citing their own experience in history, the Canadian chairman stated that although that tragedy is history, current responses focus on averting unnecessary tragedies in the present.

The Inter-Church Committee for Refugees (ICCR), formed in 1980, now numbers nine major church groups: The Anglican Church of Canada, Canadian Federation of Baptists, Canadian Confederation of Catholic Missions, Canadian Society of Friends, Council of Christian
Reformed Churches, Evangelical Lutheran Church of Canada, Mennonite Central Committee, the Salvation Army and the United Church of Canada. A chairperson, elected for a two year period, becomes the spokesperson for the organization. ICCR funds are derived from its member churches and spent on projects as determined by the members and within the organization's mandate. ICCR coordinates policies of the national churches with respect to refugee concerns and Canadian government policies. Similarly, it monitors the world refugee situation, UNHCR's work and Canadian responses. When the UNHCR expressed concern that Canada was on the list of probable countries putting forth 'no appeal' measures in the refugee determination process, ICCR prepared a brief to promote its views among assembled agencies and government delegations at the 38th Executive Committee of UNHCR (EXCOM),

When the Canadian government announced its 1988 government financed refugee resettlement level of 13,000 (an increase of 1,000 from 1987), ICCR recommended: a) 15,000 government financed places as a minimum interim level; and b) reaffirmed intake of 40,000 refugees as a more humanitarian and just level within an expanded annual immigration levels determination.

Network communication amongst organizations has propagated and therefore made the message of effective advocacy more powerful. Indeed, the process is a legacy and has often transformed ideology into morally elevated forms of social policy and concomitant action. It appears evident that response from the private sector has not only been evoked by a sense of moral outrage against social injustice but by spiritual values and historical experiences. Thus, in the past as in the present, individuals and non-governmental organizations continue to support their own ethnic and religious members from afar, as well as the stranger in their midst. Response has often been strongest from communities who suffered most grievously in the past as a result of the immigration policies which have scarred our history. Their concern is to prevent a return to restrictive and repressive policies because "if you forget the badness of your history, you are doomed to recreate it."

Noreen Nimmons is a Doctoral Fellow at the Refugee Documentation Project, York University, Canada.

(C) Authors, 1987. This open-access work is licensed under a Creative Commons Attribution-NonCommercial 4.0 International License, which permits use, reproduction and distribution in any medium for non-commercial purposes, provided the original author(s) are credited and the original publication in Refuge: Canada's Journal on Refugees is cited. 


\section{Assessing Claims, MCCC Cont'd from page 4}

M-was imprisoned and tortured for a month. When let go as a result of public outcry $\mathrm{M}$ fled to Los Angeles. Recently a co-worker in Los Angeles was kidnapped for two days. Other co-workers were raped and harassed. Nineteen persons were named on a death list. $\mathrm{M}$ - moved to Chicago and asked our help to apply for asylum at the Canadian Consulate. But last week, "Death to CISPES" was painted across the door of the office of the Committee in Solidarity with the People of El Salvador. If anyone is hurt or killed, we believe others will anxiously be seeking asylum at the Canadian border.

Our main concern relates to the screening provisions, meaning the restrictions on access to the hearing before the Refugee Division. These restrictions are twofold: 1) whether a claimant is eligible to have their claim heard; and 2) whether the claim is credible.

\section{Eligibility, Safe Third Country and Prior Rejection (S.48.1 (1))}

One important question of eligibility in Section 48.1 (1) is the basis on which a claimant could be held ineligible if he or she "came to Canada from a country that has been prescribed as a safe third country..." This provision takes the focus away from the individual's situation and places the focus on the country. Most Western countries, and others too, are generally safe. But they are not necessarily safe for the person in question. Also, when the government would draw up a list of safe countries, it could well be influenced by various foreign policy, factors and not just refugee concerns.

Two secondary provisions related to safe country merit further discussion. It appears that if the adjudicator and the Refugee Division member found that a person came to Canada from a country on the 'safe third country' list, then before declaring that claimant ineligible, they would also need assurance: a) that the claimant would 'be allowed to return' to that 'safe third country'; or b) that the claimant 'has a right to have the claim determined therein.'

First, what does it mean to be 'allowed to return?' Is protection implied or could that 'safe third country' send the person back to his or her country of origin, which the claimant may have fled because of a 'wellfounded fear of persecution.' This is not

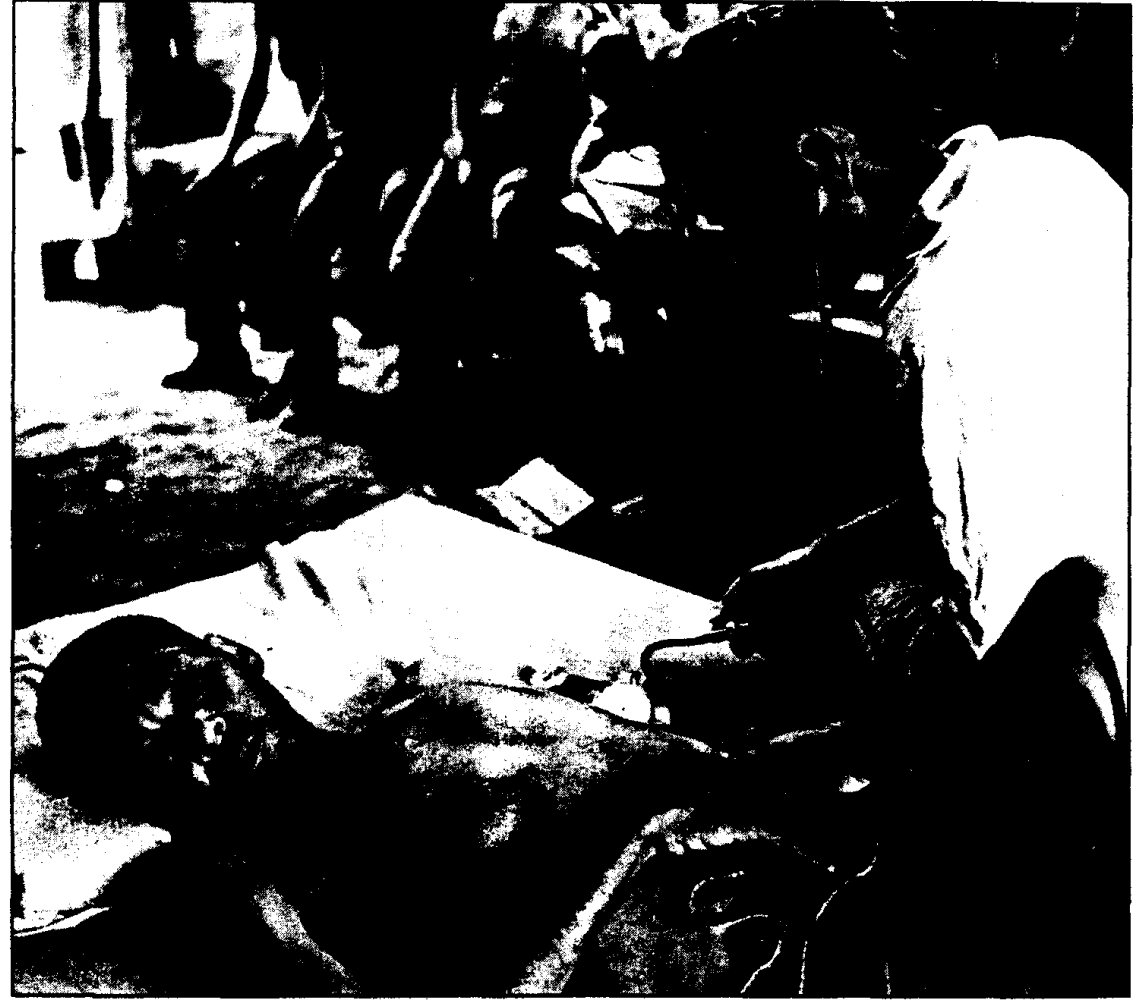

Salvadoran refugees in Honduran medical clinic.

PHOTO: UNHCR

inconceivable. If the U.S. were declared a 'safe third country' for people from Central America, for example, then a Salvadoran might well be sent back to El Salvador.

Secondly, what does it mean to have a right to have one's claim determined in that 'safe third country?' Does it mean that the person would have a right to be heard on the merits of their case? Does it mean that the person could be 'heard' in the manner that Bill C-55 proposes to 'hear' people? When 'heard' before an adjudicator and a Refugee Division member is there not then the possibility that the claimant would be held ineligible for a hearing on the 'merits' of one's case? Does it imply that a country must have a fair claims process, at least as fair as Canada's?

Thirdly, relating to process, the adjudicator and the Refugee Division member would need to be sure of only one of these two possibilities. In other words, if a person were (a) 'allowed to return' to that 'safe third country' but not (b) have the right to have his claim determined in that country, then according to the proposed wording he would still be sent back there. But to what? If he cannot have his claim heard in that country, he would surely be sent back to his country of origin eventually. To us, this provision makes the safe third country concept harsh. Is that what was intended?

Considering the inquiry procedure from the perspective of the claimant, it appears he or she would need to establish that neither of the two possibilities existed in order to avoid being sent back. In other words, the claimant would have to disprove two possibilities, both of which in the current wording are defined very vaguely. The grave difficulties faced by the claimant are compounded by the facts that the general burden of proof at the inquiry is on the claimant, per Section 48.(2), and that the inquiry is to be held within 72 hours of arrival.

Credible Basis, sections 48.1(4) (a) and (b)

If a claimant passes the eligibility tests, he or she must still pass the 'credible basis' test before the Refugee Division and discuss their fear of persecution. In determining 'credibility' the section proposes that

Cont'd on page 12 


\section{Senate Brief, ICCR Cont'd from page 7}

Protocol. The rights of a refugee are denied without just process as required by Charter section 7 .

The measure would not deter smugglers as intended. The captain faces no penalties. But passengers would face travel under appalling conditions. The risk to refugees may be cruel and unusual treatment which conflicts with Charter section 12 .

The ICCR recommends that the legislature replace Clause 8 with a measure which will bring vessels within Canadian waters to port, seize the ship and charge the captain. This will more effectively carry out the stated purpose of controlling abuse and deterring smugglers in a manner consistent with the Convention and Protocol and the Charter:

91.1 Where the Minister believes on reasonable grounds that a vehicle within

a) the internal waters of Canada, b) the Territorial sea of Canada, $x$ is bringing any person into Canada in contravention of this Act or the regulations, the Minister may direct that the vehicle be escorted to the nearest port of disembarkation and any such direction may be enforced as is reasonably necessary.

Lines $46-47$ on page 7 should be deleted.

5) Penalties for Unscrupulous Agents. Clause 9 (s.95(1), (2), (3) \& (4)

The sections of this clause define who will be targeted for penalties. The clause definition provides penalties for anyone who knowingly aids, abets, organizes, etc., the coming to Canada of a person who does not have a visa, passport or travel document.

Documents are not the issue; covert entry is. The clauses are not effective in focussing penalties on smugglers and unscrupulous consultants. Voluntary agencies working with refugees would be liable for exercising their freedom of conscience in possible violation of Charter section 2 . The special measures for sea travel may violate Charter section 15 by discriminating according to method of travel.

These measures are new. At present, the
Immigration Act 1976 prohibits a person from arriving without a valid visa. It prohibits persons to take actions counter to the Act. However, the Act also undertakes to protect refugees under Convention and Protocol obligations and intends a humanitarian tradition towards the displaced and persecuted. For this reason, we believe that only in the last year have any prosecutions been attempted and with little success to date.

Measures $95(1)$ and 95(2) have been weakened by the Minister's public promise that they will not be applied to church groups. A smuggler may now claim discrimination, under Charter section 15, to avoid application of these clauses. The clauses should be changed for more effective application.

The ICCR recommends that the legislature replace Clause 9 (s. 95(1) \& (2)) with measures which protect Canadians who continue the humanitarian tradition towards the displaced and persecuted, as intended by the Immigration Act 1976.

95.1 Every person who knowingly brings or attempts to bring or otherwise knowingly organizes, induces, aids or abets or attempts to organize aid or abet any other person to come to Canada in a clandestine manner is guilty of an offence and liable...

95.2 Every person who knowingly brings or attempts to bring or otherwise knowingly organizes, induces, aids or abets or attempts to organize aid or abet any group of ten or more persons to come to Canada in a clandestine manner is guilty of an offence and liable...

\section{6) Search and Seizure Clause 11 (s.103.02)}

An immigration officer may enter a place, including a home, on the basis that "there are reasonable grounds to believe that there may be found... any thing" which may afford evidence with respect to possibly bringing a group of ten or more undocumented arrivals to Canada. This is unprecedented in Canadian law. The Customs Bill 59, 1985, passed by the present government is but one example of so few safeguards for the rights of individuals. The clause seems to violate Charter section 8 , security from unreasonable search and seizure. Are these powers necessary? Especially in light of the fact that there appeared to be adequate provisions to deal with the Sikh arrivals.

The ICCR recommends that Clause 11 be deleted from Bill C-84. In any event, there must be better safeguards for the rights of individuals involved.

\section{7) Detention Clause 12 (s. 104.1)}

The clause allows 7 days detention with limited review provisions for persons who cannot satisfy an immigration officer of their identity or whom the officer believes to be a security risk. If the Minister files a detention certificate, detention will be for 21 days. The clause limits the authority of an immigration adjudicator to review detention orders, does not require that the detainee be advised of the reasons for detention and does not allow right to counsel. These points are all important safeguards for the individual against arbitrary detention. The Inter-Church Committee for Refugees believes that this conflicts with Charter sections $9,10,7$.

The ICCR Recommends that the Legislature replace clause 12 with increased safeguards for individual human rights, such as those suggested by Parliament's Standing Committee. In any event, the present measures of clause 12 should be deleted.

In conclusion, the ICCR is grateful for the opportunity to present its humanitarian concerns on behalf of its extensive membership through this brief to the Senate Standing Committee on Legal and Constitutional Affairs. It is our firm belief that this legislation should respond to the legitimate concerns of Canadians in a manner which will ensure full constitutional safeguards for the rights of the individuals involved.

Good effective legislation should be our common goal. 
Library Serials Dept

University of Toronto

TORONTO ON

M5S I AS

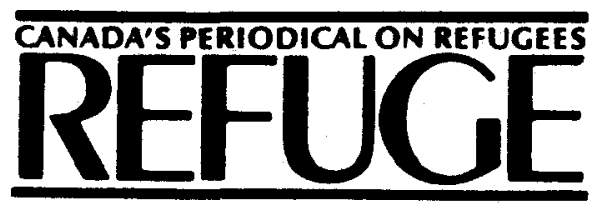

c/o Refugee Documentation Project, York University 4700 Keele Street, North York. Ontario M3 IP3

Postage Paid in Toronto Second Class Mail Registration No. 551a Return Postage Guaranteed

erto not produced refugees, might nevertheless begin doing so.

On the other hand, if the intention is that the adjudicator and Refugee Division member be permitted to take other factors into account then those should be stated explicitly. A new paragraph could state: "... matters that could affect the security of the claimant."

\section{Conclusion}

whether these sections permit the adjudicator and Refugee Division member to consider other factors as well. If not, then this remains an unsatisfactory provision. Some people fleeing countries which have relatively good human rights records have nevertheless been recognized as refugees. Also, in a crisis, a country which has hith-
We have dealt only with certain concerns that relate to the screening. If no changes are made then, in our view, Bill C-55 could close the door at the border for many deserving people.

Alternatively, if the concerns about the screening inquiry that we have identified are incorporated in amendments to the bill, then that inquiry would be somewhat like a hearing on the merits before the Refugee Division. This raises the question: why not send the claimants to a hearing before that Division in the first place. We would suggest, respectfully, that the option be considered seriously.

We have formulated this submission primarily from the perspective of our involvement with refugees. We know that as a Parliamentary Committee you will need to consider a range of other factors too. Your task of establishing a system that will be both fair and efficient in the years ahead, is difficult. We thank you for hearing us and assure you of our prayers and best wishes as you give yourselves to that task.

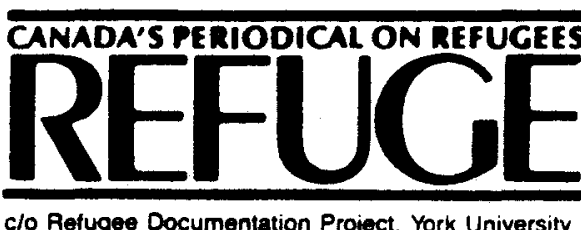

A700 Keele Street, North Y

I wish to become a friend of the Refugee Documentation Project for the 19871988 academic year. I understand that all friends receive Refuge as well as information on the research activities of the RDP. My cheque for $\$ 25$ (or made payable to the Refugee Documentation Project is enclosed.

Name

Organization

Address

City Province or State

Country Postal Code 